\title{
Purification of an Aspergillus oryzae Metallo-proteinase by Talopeptin-aminohexyl-Sepharose and Its Properties
}

\author{
Naoya Kasai, Ken-ichi Fukuhara and Sawao Murao \\ Laboratory of Applied Microbiology, Department of Agricultural Chemistry, \\ University of Osaka Prefecture, Sakai 591, Japan
}

Received December 2, 1983

\begin{abstract}
Simple and speedy purification of Aspergillus oryzae metallo-proteinase was performed using Talopeptin-aminohexyl-Sepharose. The properties of the metallo-proteinase were: optimum $\mathrm{pH}$ 6.5; pH stability, $\mathrm{pH} 5 \sim 11$; optimum temperature, $50^{\circ} \mathrm{C}$; and molecular weight 42,000 (SDS electrophoresis). These results were similar to those of neutral protease I from Aspergillus oryzae reported by Nakadai et al. This metallo-proteinase was compared with others from microbes using the metallo-proteinase inhibitors FMPI, PLT, and Talopeptin. The metallo-proteinase is unique in the point at which FMPI and PLT gave nearly stoichiometrical inhibition.
\end{abstract}

A metallo-proteinase is a proteinase with zinc atoms in its catalytic residues. ${ }^{1)}$ Purification and some properties of metallo-proteinases from various microbial origins have been reported by several workers. ${ }^{1)}$ These reports indicated that despite the difference of their origins, these metallo-proteinases have similar properties, for example, molecular weight, amino acid composition, specificity against synthetic substrates, and splitting points against the insulin B-chain. However, the properties of metallo-proteinases from molds are less well-understood than those from bacteria, because purification of metallo-proteinases from molds is difficult. Molds produce both metallo-proteinases and serine-proteinases usually less of the latter. Moreover, metalloproteinases from molds are often inactivated by contaminating serine proteinase under purification conditions. Therefore, a new purification method to obtain metallo-proteinases from molds is necessary.

In this report we will describe a simple and speedy purification of Aspergillus oryzae metallo-proteinase using Talopeptin-aminohexyl-Sepharose and will describe some properties of the purified enzyme. Comparison of the reaction of the enzyme and other bacterial metallo-proteinases with specific metallo-proteinase inhibitors, FMPI,${ }^{2}{ }^{5)}$ PLT, ${ }^{5)}$ and Talopeptin, ${ }^{6 \sim 8)}$ is also reported.

\section{MATERIALS AND METHODS}

Chemicals and materials. Sepharose 4B was purchased from the Pharmacia Japan Co., Tokyo. $N$-ethyl- $N^{\prime}$ (3-dimethylaminopropyl) carbodiimide hydrochloride (EDC) and 1,6-di-aminohexane were from the Wako Pure Chem. Industry Co., Osaka.

Enzymes and substrates. Metallo-proteinase of Asp. oryzae was purified from Biodiastase ${ }^{\circledR}$ which was kindly supplied by the Amano Pharmacy Co., Nagoya. Metalloproteinase of Streptomyces griseus was further purified from an enzyme powder of neutral proteinase from Streptomyces griseus, ${ }^{9)}$ Type V, the Sigma Chem. Co., St. Louis, using Talopeptin-aminohexyl-Sepharose and gel filtration. Thermolysin ${ }^{10)}$ ( 3 times crystallized) was kindly supplied by the Daiwa Kasei Co., Osaka. The crystalline metallo-proteinase of Pseudomonas aeruginosa ${ }^{11)}$ IFO3455 was kindly donated by Dr. Morihara of the Shionogi Co., Osaka. The crystalline metallo-proteinases of Bacillus subtilis var. amylosacchariticus ${ }^{12)}$ and Bacillus amyloliquefaciens $^{13)}$ were kindly donated by Professor Tsuru of Nagasaki University. Casein according to Hammarsten was purchased from the Wako Pure Chemical Co., Osaka.

Inhibitors. The metallo-proteinase inhibitors, FMPI and

\footnotetext{
Abbreviations: FMPI, $N$-phospho-L-phenylalanyl-L-arginine; PLT, $N$-phospho-L-leucyl-L-tryptophan; Talopeptin, 6-deoxy- $\alpha$-L-talopyranosyloxyphospho-L-leucyl-L-tryptophan; $\mathrm{AH}$, aminohexyl.
} 
Talopeptin were purified from culture filtrates of Streptomyces rishiriensis NK-122 2 4) and Streptomyces mozunensis MK-23, ${ }^{6 / 8)}$ respectively. PLT was prepared from Talopeptin by alkaline hydrolysis as described previously. ${ }^{5)}$

Assay methods. Activities of enzymes were assayed by measuring caseinolysis according to the methods described previously. ${ }^{2)}$

Measurement of protein concentration. The protein concentrations of sample were estimated on the basis of their absorption at $280 \mathrm{~nm}$.

Amino acid analysis. Purified enzyme protein was hydrolyzed with $6 \mathrm{~N} \mathrm{HCl}$ at $110^{\circ} \mathrm{C}$ in evacuated sealed tubes for 24,48 , and $72 \mathrm{hr}$. Amino acid analysis was performed by a Hitachi High Speed Amino Acid Analyzer KLA-835. The amounts of cysteine and tryptophan were determined according to the methods of Moore ${ }^{14)}$ and Goodwin, ${ }^{15}$ respectively.

Difference spectrum. Difference spectra were measured in $0.1 \mathrm{M}$ Tris- $\mathrm{HCl}$ buffer, $\mathrm{pH} 7.5$, containing $10 \mathrm{~mm}$ calcium acetate using a Hitachi Spectrophotometer 320.

Preparation of Talopeptin-aminohexyl-Sepharose. Forty milliliters of Sepharose 4B was washed with $1 \mathrm{M} \mathrm{NaCl}$ and deionized water and then mixed with $20 \mathrm{~g}$ of $\mathrm{CNBr}$ in $40 \mathrm{ml}$ deionized water in an ice bath. The activated Sepharose 4B was mixed with $8 \mathrm{~g}$ of 1,6-diaminohexane in $40 \mathrm{ml} \mathrm{de-}$ ionized water at $\mathrm{pH} 10.5$ and stood overnight. Then, eighty-five milligrams of Talopeptin was mixed with the prepared AH-Sepharose 4B in $40 \mathrm{ml}$ deionized water and $400 \mathrm{mg}$ of EDC was added. The mixture was left at room temperature, $\mathrm{pH} 6$ with gentle stirring overnight. The yield of immobilization of Talopeptin was $82 \%$. The column was equilibrated with $0.5 \mathrm{M} \mathrm{NaCl}$ before use.

\section{RESULTS AND DISCUSSION}

Purification of Asp. oryzae metallo-proteinase

Step. 1. Affinity chromatography on Talopeptin-AH-Sepharose. Fifty grams of Biodiastase $^{\circledR}$ enzyme powder was dissolved in $500 \mathrm{ml}$ of $0.5 \mathrm{M} \mathrm{NaCl}$ containing $10 \mathrm{mM}$ calcium acetate and centrifuged at $10,000 \times g$ for $10 \mathrm{~min}$ at $0^{\circ} \mathrm{C}$. The supernatant was applied to a column of Talopeptin-AH-Sepharose 4B $(3.5 \times 4 \mathrm{~cm})$ at a flow rate of $150 \mathrm{ml} / \mathrm{hr}$. The column was washed with the same eluent, and then the metallo-proteinase was eluted with $0.1 \mathrm{M}$ Tris containing $0.5 \mathrm{M} \mathrm{NaCl}$ and $10 \mathrm{~mm}$ calcium acetate, $\mathrm{pH}$ 9.5. Figure 1 shows the

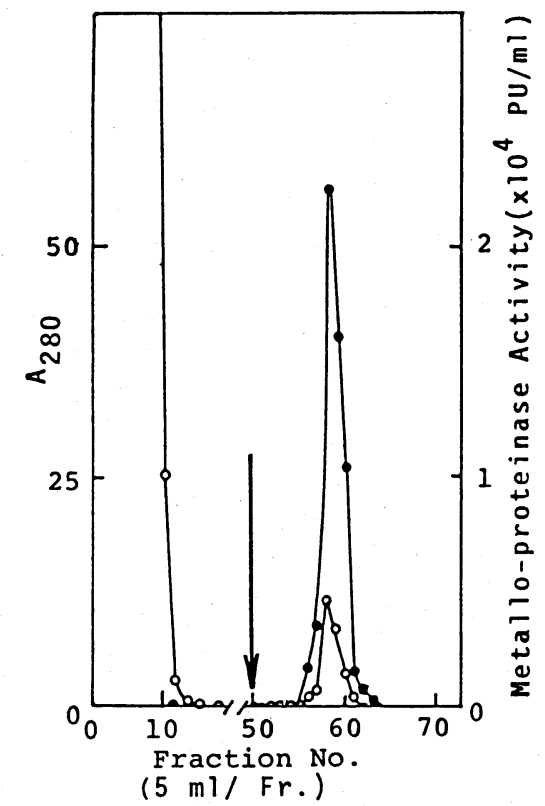

Fig. 1. Elution Profile of Asp. oryzae Metalloproteinase on a Talopeptin-AH-Sepharose Column.

Five hundred milliliters of enzyme solution (Biodiastase $100 \mathrm{mg} / \mathrm{ml})$ was applied to a column $(3.5 \times 4 \mathrm{~cm})$. The vertical arrow indicates the position where the eluate solution was changed to $0.1 \mathrm{M}$ Tris $-0.5 \mathrm{M} \mathrm{NaCl}$ containing $10 \mathrm{~mm}$ calcium acetate, $\mathrm{pH}$ 9.5. Flow rate: $150 \mathrm{ml} / \mathrm{hr}$ (bofore vertical arrow) and $25 \mathrm{ml} / \mathrm{hr}$ (after vertical arrow); Fractionation: $5 \mathrm{ml} /$ tube. Symbols: O, O.D. at $280 \mathrm{~nm}$; O, proteinase activity.

elution profile. Proteinase activity of the eluated solution was inhibited completely by $10 \mathrm{~mm}$ EDTA; therefore, it is evident that the solution contains metallo-proteinase free from serine-proteinase. Thermolysin and Streptomyces griseus metallo-proteinase could also be absorbed on to the column.

Step 2. Gel filtration on Sephadex G-100. The enzyme solution obtained above was condensed to $20 \mathrm{ml}$ using a Diafilter MC-50 in an ice bath. Ten milliliters of condensed sample was applied onto a column of Sephadex G-100 $(2.5 \times 95 \mathrm{~cm})$, previously equilibrated with $10 \mathrm{~mm}$ calcium acetate. The sample was eluted with the same eluent and $5 \mathrm{ml}$ fractions were collected. A typical elution profile is shown in Fig. 2. Three kinds of metallo-proteinases were found. Since the amounts of metalloproteinases in peaks of $\mathrm{A}$ and $\mathrm{C}$ were smaller 
Table I. Summary of Purification of Asp. oryzae Metallo-proteinase

\begin{tabular}{lccccc}
\hline \multicolumn{1}{c}{ Procedures } & $\begin{array}{c}\text { Volume } \\
(\mathrm{ml})\end{array}$ & $\begin{array}{c}\text { Total act. } \\
(\mathrm{PU})\end{array}$ & $\begin{array}{c}\text { Total } A_{280} \\
\left(A_{280} \times \mathrm{ml}\right)\end{array}$ & $\begin{array}{c}\text { Specific act. } \\
\left(\mathrm{PU} / A_{280}\right)\end{array}$ & $\begin{array}{c}\text { Yield } \\
(\%)\end{array}$ \\
\hline Biodiastase powder & 500 & $2,420,000$ & 499,000 & 4.8 & 100 \\
Talopeptin-AH-Sepharose & 478 & $1,950,000$ & 1,030 & 1,890 & 80.7 \\
Sephadex G-100 & 49 & 510,000 & 320 & 1,590 & 21.1 \\
\hline
\end{tabular}

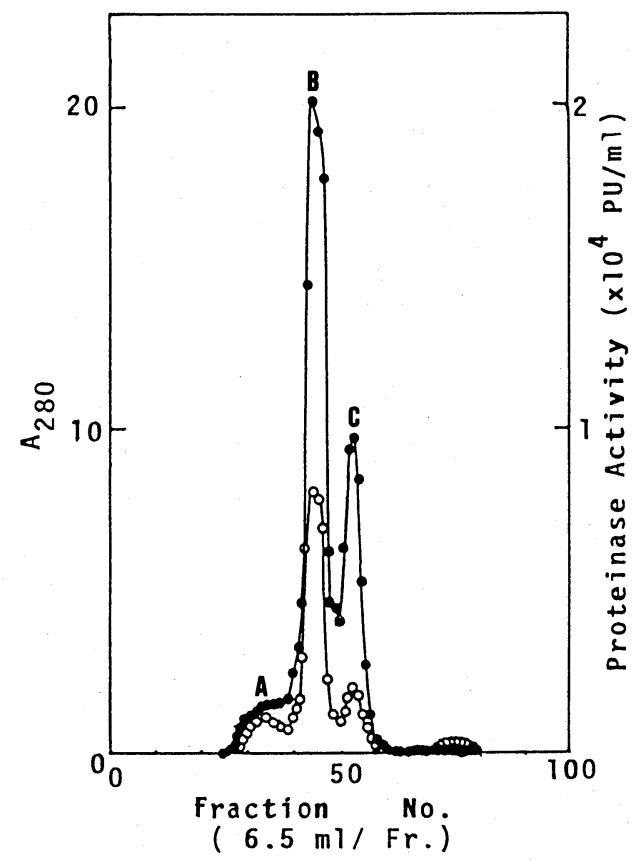

FIG. 2. Gel Filtration of Asp. oryzae Metallo-proteinase on a Sephadex G-100 Column.

After treatment with Talopeptin-AH-Sepharose Asp. oryzae metallo-proteinase was applied to a column of Sephadex G-100 $(2.5 \times 95 \mathrm{~cm})$. Fractionation: $6.5 \mathrm{ml} /$ tube. Symbols: O, O.D. at $280 \mathrm{~nm}$;, proteinase activity.

than that of peak B, the metallo-proteinase in peak B was purified hereafter. The metalloproteinase in peak $B$ was pooled and then ammonium sulfate was added in an ice bath until the concentration of ammonium sulfate reached 0.9 saturation. The white cloudy mixture was centrifuged at $10,000 \times g$ for $10 \mathrm{~min}$ at $0^{\circ} \mathrm{C}$ and the precipitate was collected. The precipitate was dissolved in $10 \mathrm{ml}$ of $10 \mathrm{~mm}$ calcium acetate, and then applied onto a column of Sephadex G-100 under the same conditions as in the first gel filtration. Fractions containing metallo-proteinase were collected

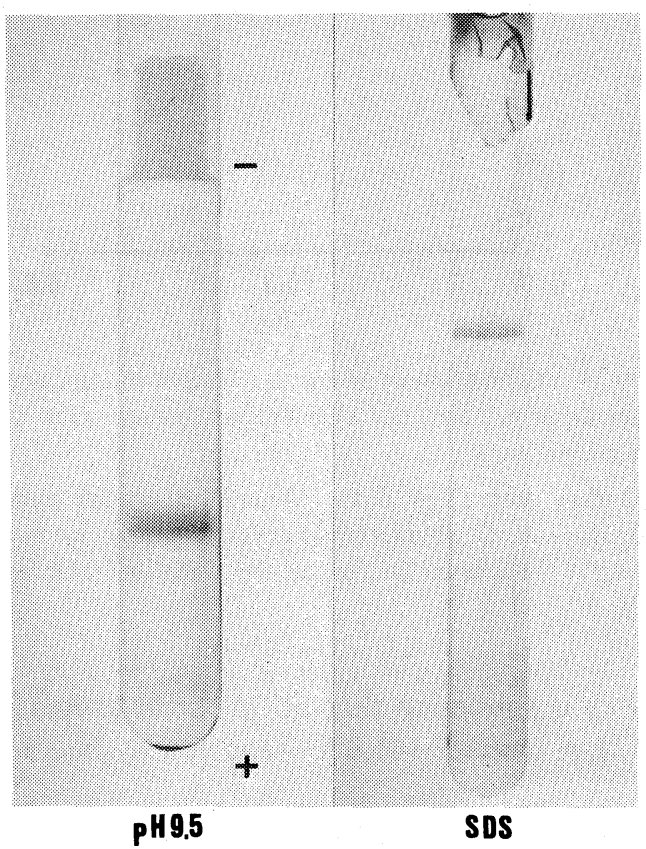

FIG. 3. Polyacrylamide Gel Electrophoresis of Asp. oryzae Metallo-proteinase.

$\mathrm{pH}$ 9.5: The sample was run in the cold room $\left(4^{\circ} \mathrm{C}\right)$ for 40 min at $4 \mathrm{~mA}$ per gel column.

SDS: The sample was run for $3 \mathrm{hr}$ at $7 \mathrm{~mA}$ of per gel column ( $\mathrm{pH} 7.2 \sim 10 \%$ gel with SDS) after reduction and denaturation with SDS and mercaptoethanol $\left(100^{\circ} \mathrm{C}\right.$ for 3 min). Protein was stained with Coomassie brilliant blue.

and stored at $-20^{\circ} \mathrm{C}$ (yield $21 \%$ ). Summary of purification was shown in Table I.

\section{Disc and polyacrylamide electrophoresis}

Purified metallo-proteinase was homogeneous by $\mathrm{SDS}^{16)}$ and polyacrylamide electrophoresis $^{17)}$ as shown in Fig. 3. Figure 4 shows a plot of $R_{\mathrm{m}}$ values against molecular weight of standard proteins and the metalloproteinase. Molecular weight of the metalloproteinase was estimated to be 42,000 . This 


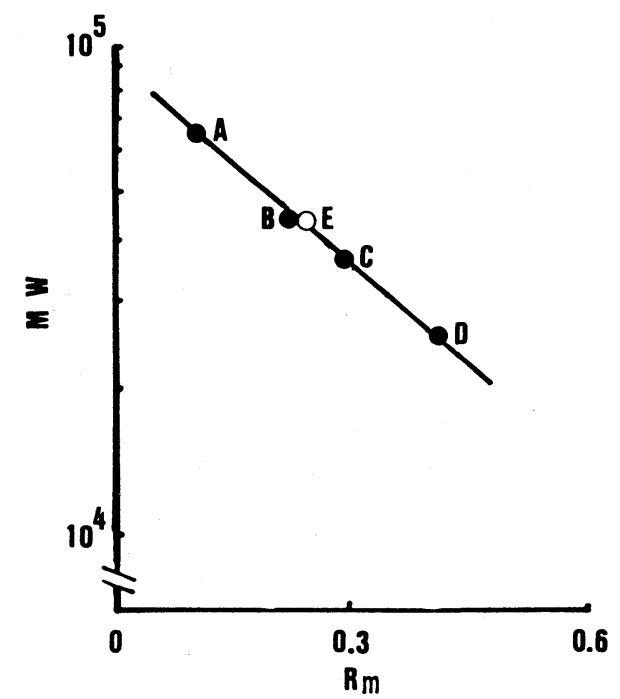

FIG. 4. Estimation of Molecular Weight of Asp. oryzae Metallo-proteinase by SDS-Polyacrylamide Gel Disc Electrophoresis.

Standard proteins: A, bovine albumin; B, egg albumin; C, thermolysin; D, chymotrypsinogen; E, Aspergillus oryzae metallo-proteinase. The conditions were the same as in Fig. 3.

value is similar to that of "Neutral protease I of Asp. oryzae" $(41,000)$ reported by Nakadai et al. ${ }^{18)}$

\section{Some properties of the metallo-proteinase}

The purified Asp. oryzae metallo-proteinase had an optimum $\mathrm{pH}$ of 6.5 ; optimum temperature of $50^{\circ} \mathrm{C}$; and $\mathrm{pH}$ stability, $\mathrm{pH} 5 \sim 11$ (at $37^{\circ} \mathrm{C}$ for $3 \mathrm{hr}$ ); $E_{280}^{1 \%}=18.2$. The optimum $\mathrm{pH}$ and $\mathrm{pH}$ stability of this enzyme are similar to those of neutral protease I of Asp. oryzae reported by Nakadai et al. ${ }^{18)}$

\section{Difference absorption spectra accompanying the enzyme-FMPI complex formation}

The ultraviolet absorption difference spectra caused by mixing thermolysin or Asp. oryzae metallo-proteinase with FMPI are shown in Fig. 5. The main peaks were seen around $295 \mathrm{~nm}$ and $285 \mathrm{~nm}$. The difference spectra of Asp. oryzae metallo-proteinase and thermolysin caused by FMPI are similar. Absorbance peak height of difference spectra are plotted against amounts of FMPI and molar ratio

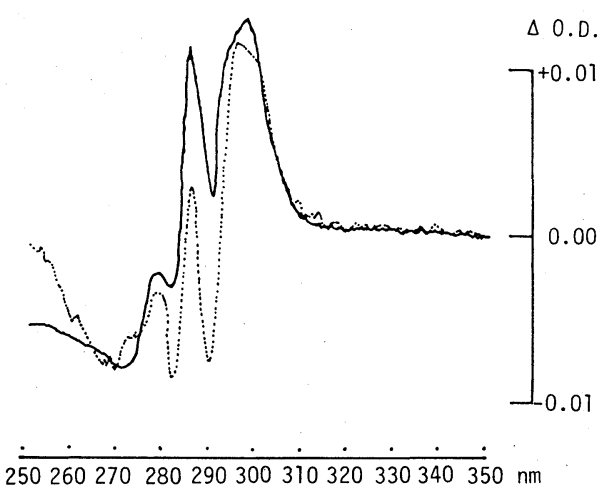

FIG. 5. Ultraviolet Absorption Difference Spectra Caused by Interaction of Thermolysin and Asp. oryzae Metallo-proteinase with FMPI.

Enzyme concentration, $3.0 \times 10^{-5} \mathrm{M}$ (based on the values of $E_{280}^{1 \%}$ and molecular weight; thermolysin: 17.65 and 37,500, Asp. oryzae metallo-proteinase: 18.2 and 42,000); FMPI concentration, $6.0 \times 10^{-5}$ M. Symbols: - - - , thermolysin; —_, Asp. oryzae metallo-proteinase.

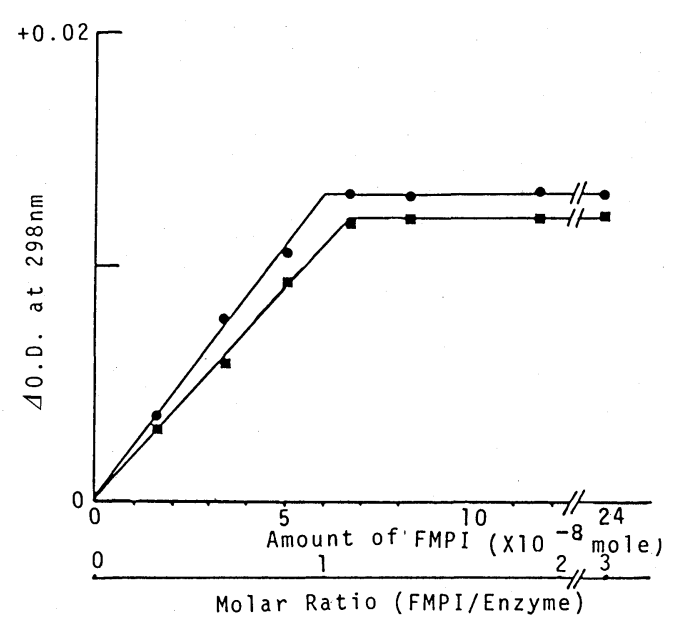

Fig. 6. Absorbance Peak of Difference Spectra was Plotted against Amounts of FMPI and Molar Ratio (Enzyme/FMPI).

Symbols: ם, thermolysin; ○, Asp. oryzae metalloproteinase (amounts of enzymes, $6 \times 10^{-8} \mathrm{~mol}$ ).

(enzyme/FMPI) as shown in Fig. 6. FMPI binds to the enzymes in the molar ratio of one to one.

\section{Amino acids composition}

Table II shows the amino acid composition of Asp. oryzae metallo-proteinase and that of thermolysin as a reference. Compared with 
Table II. Comparison of Amino Acid Compositions of Asp. oryzae METAllo-PROTEINASE AND THERMOLYSIN

\begin{tabular}{|c|c|c|}
\hline Amino acid & Asp. oryzae ${ }^{a}$ & Thermolysin $^{19)}$ \\
\hline Lys & 3 & 12 \\
\hline His & 9 & 9 \\
\hline Arg & 18 & 10 \\
\hline Try & 4 & 55 \\
\hline Asp & 72 & 43 \\
\hline Thr & 30 & 23 \\
\hline Ser & 24 & 23 \\
\hline Glu & 36 & 20 \\
\hline Pro & 27 & 8 \\
\hline Gly & 45 & 36 \\
\hline Ala & 42 & 28 \\
\hline Cys- $\mathrm{SO}_{3} \mathrm{H}$ & 1 & 0 \\
\hline Val & 9 & 24 \\
\hline Met & 9 & 2 \\
\hline Ile & 12 & 18 \\
\hline Leu & 30 & 17 \\
\hline Tyr & 24 & 29 \\
\hline Phe & 12 & 10 \\
\hline Ammonium & 45 & 38 \\
\hline Total & 407 & 317 \\
\hline
\end{tabular}

a Based on a molecular weight of 42,000 .

thermolysin, Asp and Pro are plentiful in Asp. oryzae metallo-proteinase.

\section{Interaction with inhibitors}

a) Inhibition against caseinolytic activity. $\mathrm{ID}_{50}$ values (moles of inhibitor necessary for $50 \%$ inhibition) and molar ratio of inhibitors to the enzymes at the values against caseinolytic activity is summarized in Table III. Asp. oryzae and St. griseus metallo-proteinases were most strongly inhibited by FMPI and PLT. The molar ratio in the case of Asp. oryzae was 0.4 . This suggests that FMPI and PLT give nearly stoichiometrical inhibition of the enzyme.

b) Effect of preincubation time on the inhibitory activity of FMPI. The enzymes were mixed with FMPI to cause $50 \%$ inhibition, and the effect of preincubation time on restoring activity was investigated. The result is shown in Fig. 7. The proteinase from Asp. oryzae was not restored even after two hours. But with the other enzymes, the proteinase activity gradually increased during the elongation of pre-
TABLE III.

\begin{tabular}{|c|c|c|c|}
\hline \multirow[t]{2}{*}{ Metallo-proteinases } & \multicolumn{3}{|c|}{$\begin{array}{l}\mathrm{ID}_{50} \text { values (upper; } \times 10^{-10} \\
\text { mol) and molar ratios } \\
\text { (bottom; inhibitor/enzyme) } \\
\text { at the values against } \\
\text { caseinolytic activity }\end{array}$} \\
\hline & FMPI & PLT & Talopeptin \\
\hline \multirow{2}{*}{ Asp. oryzae } & 1 & 1 & 16 \\
\hline & 0.4 & 0.4 & 5 \\
\hline \multirow{2}{*}{ B. thermoproteolyticus } & 5 & 2 & 13 \\
\hline & 5.6 & 2.2 & 15 \\
\hline \multirow{2}{*}{$\begin{array}{l}\text { B. subtilis var. } \\
\text { amylosacchariticus }\end{array}$} & 800 & 9 & 1200 \\
\hline & 440 & 5 & 660 \\
\hline \multirow{2}{*}{ B. amyloliquefaciens } & 1000 & 9 & 1800 \\
\hline & 430 & 4 & 790 \\
\hline \multirow{2}{*}{ Ps. aeruginosa IFO 3455} & 54 & 13 & 26 \\
\hline & 29 & 7 & 14 \\
\hline \multirow{2}{*}{ St. griseus } & 1 & 1 & 11 \\
\hline & - & - & - \\
\hline
\end{tabular}

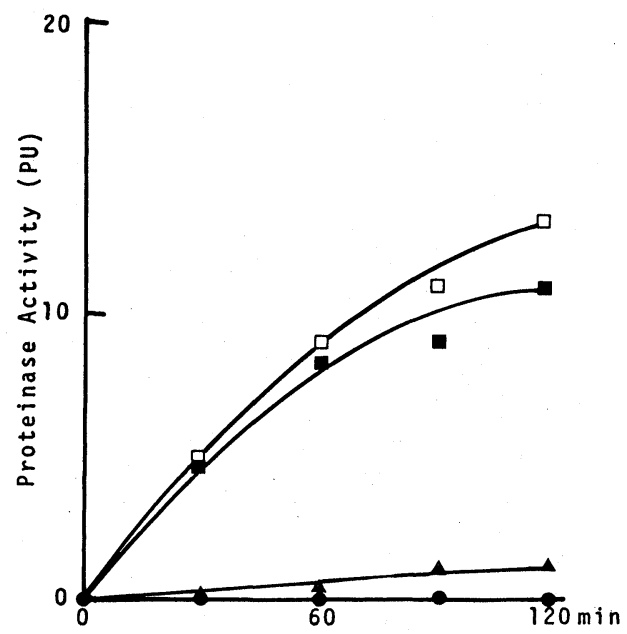

FIG. 7. Effect of Preincubation Time on Reversing Inhibition by FMPI.

Various enzyme solutions $(0.1 \mathrm{M}$ Tris- $\mathrm{HCl}$ buffer, containing $2 \mathrm{~mm}$ calcium acetate, $\mathrm{pH} 7.5,40 \mathrm{PU}$ ) and FMPI (in the same buffer solution) were mixed and incubated at $37^{\circ} \mathrm{C}$, and then assayed for restored proteinase activity. Symbols: ○, Asp. oryzae; $\mathbf{\Delta}$, St. griseus; $\mathbf{\square}$, thermolysin; $\square$, Ps. aeruginosa IFO 3455. 
incubation time. These results are considered as follows: in the former case, all of the FMPI had formed stable enzyme-FMPI complexes, so that FMPI was not inactivated, but in the latter case, an excess of FMPI was needed for $50 \%$ inhibition, so that free FMPI was decomposed as described previously, ${ }^{2)}$ and consequently the proteinase activity was restored. These results indicated that FMPI binds most tightly to Asp. oryzae metallo-proteinase and supported the results in Table III.

Acknowledgment. This work was supported in part by a Grant-in-Aid for Scientific Research from the Ministry of Education, Science and Culture of Japan.

\section{REFERENCES}

1) H. Matsubara and J. Feder, "The Enzymes," Vol. 3, ed. by P. D. Boyer, Academic Press, New York, 1960 , p. 765.

2) S. Murao, N. Kasai, Y. Kimura, K. Oda and K. Fukuhara, Agric. Biol. Chem., 46, 855 (1982).

3) S. Murao, N. Kasai, Y. Kimura and K. Oda, Agric. Biol. Chem., 46, 2979 (1982).

4) N. Kasai, K. Fukuhara and S. Murao, Agric. Biol. Chem., 46, 2607 (1982).
5) N. Kasai, K. Fukuhara, K. Oda and S. Murao, Agric. Biol. Chem., 47, 2915 (1983).

6) S. Murao, K. Katsura, K. Fukuhara and K. Oda, Agric. Biol. Chem., 3, 701 (1980).

7) K. Fukuhara, M. Katsura and S. Murao, Agric. Biol. Chem., 46, 1707 (1982).

8) K. Fukuhara, S. Murao, T. Nozawa and M. Hatano, Tetrahedron Lett., 23, 2319 (1982).

9) Y. Narahashi, K. Shibuya and M. Yanagita, $J$. Biochem., 64, 427 (1968).

10) S. Endo, J. Ferment. Technol., 40, 346 (1962).

11) K. Morihara, H. Tsuzuki and T. Oka, Arch. Biochem. Biophys., 123, 572 (1968).

12) D. Tsuru, T. Yamamoto and K. T. Yasunobu, Agric. Biol. Chem., 30, 651 (1966).

13) J. D. McConn, D. Tsuru and K. T. Yasunobu, J. Biol. Chem., 239, 370 (1966).

14) S. Moore, J. Biol. Chem., 238, 235 (1963).

15) T. W. Goodwin and R. A. Morton, Biochem. J., 40, 628 (1964).

16) K. Weber and M. Osborn, J. Biol. Chem., 244, 4406 (1969).

17) B. J. Davis, Ann. N. Y. Acad. Sci., 121, 404 (1964).

18) T. Nakadai, S. Nasuno and N. Iguchi, Agric. Biol. Chem., 37, 2695 (1973).

19) T. Ohta, Y. Ogura and A. Wada, J. Biol. Chem., 241, 5919 (1966). 